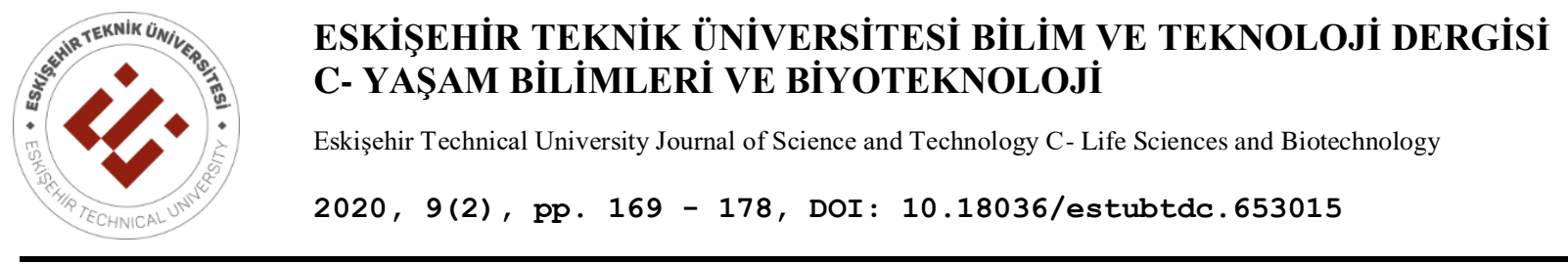

\title{
HEAVY METAL-ASSOCIATED CHROMOSOMAL ABERRATIONS IN SUBTERRANEAN MAMMALS (RODENTIA: SPALACIDAE) FROM POLLUTED SOILS
}

\author{
Tuba YAĞCI ${ }^{1} *$ (D), Rafig GURBANOV ${ }^{1}$ (iD
}

${ }^{1}$ Department of Molecular Biology and Genetics, Faculty of Science and Arts, Bilecik Şeyh Edebali University, Bilecik, Turkey

\begin{abstract}
In this preliminary study, the chromosomal aberrations were investigated for the first time in the subterranean Nannospalax xanthodon species. The locations in Bilecik province where the samples were collected were divided into the polluted and nonpolluted area. The concentrations of cadmium, copper, nickel, lead, and zinc were measured on the Atomic Absorption Spectrometer in the soil samples and liver tissues of the animals. The metal levels detected in liver tissues were found to be higher than the metal levels of soil samples. Therefore, Nannospalax species were considered as appropriate bioindicators for the determination of terrestrial pollution. The examination of chromosomes revealed intense deletions and fragmentations in the chromosome plates of samples from the polluted area. It was concluded that these chromosome aberrations can be associated with metal pollution.
\end{abstract}

Keywords: Heavy metal, Chromosomal aberrations, Subterranean life, Nannospalax xanthodon

\section{INTRODUCTION}

Natural processes (volcanoes, erosion, and spring water) and anthropogenic activities (mining, fossil fuel, agriculture) cause the accumulation of heavy metals in the soil which are toxic for plants, animals, and humans [1]. Exposure to a wide range of non-essential heavy metals like lead $(\mathrm{Pb})$, mercury $(\mathrm{Hg})$ and cadmium $(\mathrm{Cd})$, and essential elements such as zinc $(\mathrm{Zn})$ and copper $(\mathrm{Cu})$ can produce toxic effects in all organisms [2]. Plants that take the heavy metal ions from the soil with their roots are primarily affected by this pollution [3]. Mammals are affected by environmental pollutants through oral, dermal, and inhalation routes. Although hair and skin provide a significant barrier to contaminants, rodents are frequently exposed to heavy metals through contaminated foods. Under the soil, various volatile contaminants and/or heavy metals bound to soil particles can be easily inhaled by mammals. Therefore, respiratory exposure is also important for some species that spend most of their time under the ground. [4,5].

Nannospalax species belonging to Rodentia are very well-adapted to subsoil life and spend almost all of their life under the ground. Their nutrients are usually sub-plant parts of the plants $[6,7]$. Considering the habitat and nutrition requirements of mole rats, there may be strong exposure to heavy metals through oral, dermal, and inhalation routes. Bioaccumulation of heavy metals and toxic elements in animals causes different modifications in bone marrow chromosomes. Detection of chromosomal disorders is considered to be highly reliable in detecting genotoxic effects induced by heavy metals and other toxic elements. Chromosomal aberrations (acentric fragments, chromatid and chromosome fractures, inversion, translocation, ring chromosome) are frequently used in detecting the mutagenic effects of chemical compounds on mammals [8,9]. Topashka et al. [10] determined the heavy metal concentrations in small mammals in Bulgaria, living in $\mathrm{Zn}, \mathrm{Cu}, \mathrm{Pb}$, and $\mathrm{Cd}$ contaminated areas. The authors of the study found a significant correlation between the heavy metal load of rodents and the frequency of chromosomal aberrations and pathological changes in erythrocytes. Agarwal et al. [11] intraperitoneally administered certain doses of copper sulfate $\left(\mathrm{CuSO} 5 \mathrm{H}_{2} \mathrm{O}\right)$ to mice at different time intervals to evaluate the toxicity of $\mathrm{Cu}$ on bone marrow chromosomes in a dose-

\footnotetext{
*Corresponding Author:tuba.yagci@bilecik.edu.tr
}

Received: 29.11.2019 Published: 30.07.2020 
dependent manner. It was noted that all administered concentrations dose-dependently increase the chromosomal aberrations such as chromatid fractures and chromosomal rearrangements in bone marrow cells. $\mathrm{Cd}$ and $\mathrm{Pb}$ are highly toxic heavy metals that affect almost all livings. By combining these two heavy metals with an insecticide cypermethrin, Nehez et al. [12] examined their genotoxic effects on bone marrow cell chromosomes in rats. Cypermethrin and $\mathrm{Pb}$ caused significant chromosomal abnormalities by forming acentric fragments.

In ecotoxicological studies conducted in Europe's terrestrial ecosystems, some small mammal species belonging to the genus Erinaceus, Apodemus, and Microtus are frequently used for the determination of environmental pollution. The chemical analysis of hair, liver, and kidney tissues from these animals was conducted to determine the bioaccumulation levels of metal and metalloid pollutants. A positive correlation was found between the soil metal concentrations and the metal concentrations determined in the various tissues of the animals. Many researchers have shown that heavy metal concentrations in rodent populations are generally associated with environmental pollution $[13,14,15]$. Although many studies revealed the relationship between the heavy metal bioaccumulation in natural populations of small mammals and environmental pollution in Continental Europe, this kind of research is not common in Turkey. Generally, the conducted studies were presented the potentially harmful effects of various drugs and chemicals on live systems by applying these substances to experimental animals in a laboratory environment. In such studies, the tested chemicals promoted DNA damage and chromosomal abnormalities.

In this preliminary study, it was aimed to determine the concentrations of $\mathrm{Cr}, \mathrm{Cd}, \mathrm{Cu}$, and $\mathrm{Pb}$ in Nannospalax xanthodon ( $N$. xanthodon) and evaluate the relationship between heavy metal bioaccumulation and chromosomal aberrations in natural environments. Besides, the suitability of using blind mice as a bioindicator species in the conservation of natural habitats of our country was investigated for the first time.

\section{MATERIAL AND METHODS}

\subsection{Sample Location}

An area where the tire recycling facility was previously located in the province of Bilecik (Pazaryeri), was grouped as polluted soils, and an area away from the settlement and roadside was grouped as nonpolluted soils (Figure 1). Adult blind mole rats (180-200 g, polluted soils: $3 \hat{\jmath} \widehat{\jmath}$, non-polluted soils: $2 \hat{\jmath} \hat{0})$ were captured from each location (approximately $60 \mathrm{~m}^{2}$ area) by a live trap which was designed previously by Yağci\&Aşan [16]. 


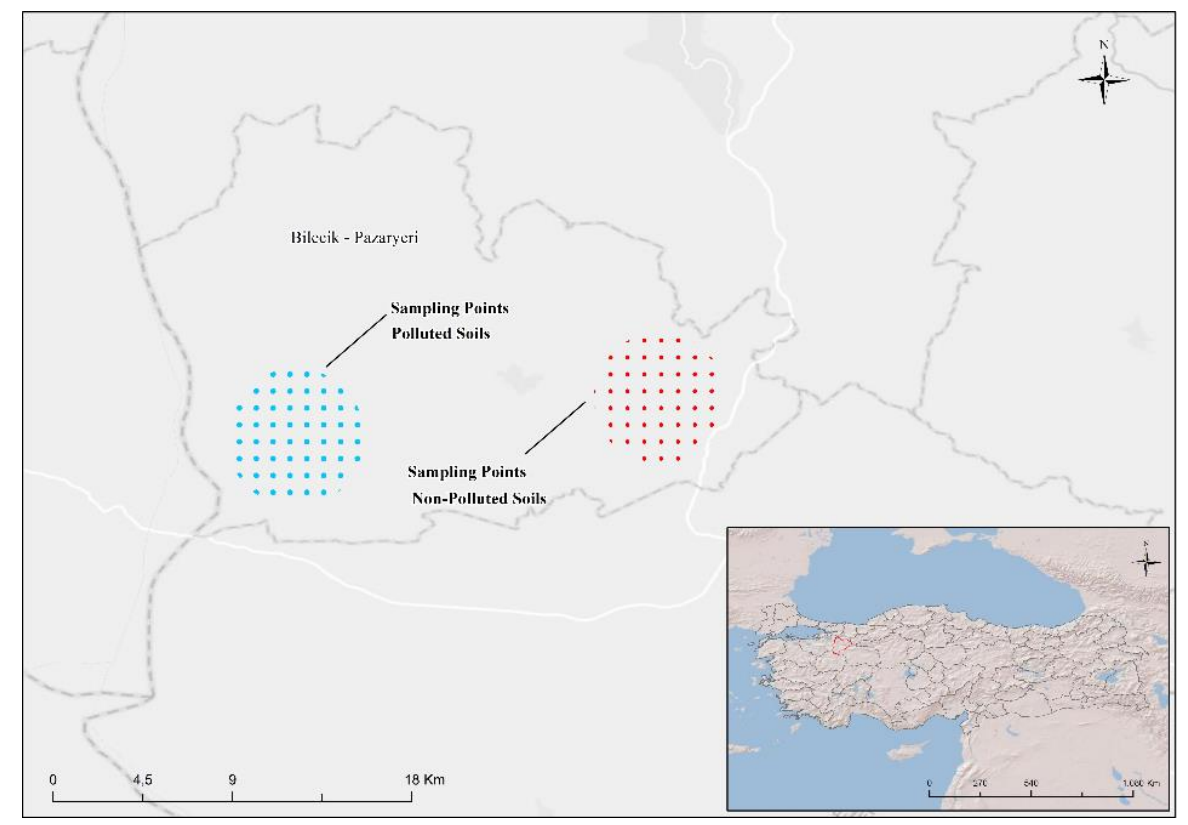

Figure 1. The locations of captured animals and collected soils

\subsection{Heavy Metal Analysis of the Soil and Biological Material}

Soil samples were taken according to Beernaert et al. [17]. The concentrations of $\mathrm{Cd}, \mathrm{Cu}, \mathrm{Cr}, \mathrm{Pb}$, and $\mathrm{Zn}$ in the soil samples were determined by Atomic absorption spectroscopy (AAS) analysis at the Eskişehir Directorate of Forestry Soil and Ecology Research Institute (Table 1). The concentrations of $\mathrm{Cd}, \mathrm{Cu}, \mathrm{Cr}, \mathrm{Pb}$, and $\mathrm{Zn}$ in liver tissues of the animals captured from the polluted and non-polluted regions were determined using AAS at Central Research Laboratory of Bilecik Şeyh Edebali University (Table 2). For metal analysis, the samples from each muscle tissue were stored at $-20^{\circ} \mathrm{C}$. Subsequently, $1 \mathrm{~g}$ of freeze-dried tissues was powdered. After the addition of $5 \mathrm{ml}$ of $\mathrm{HNO}_{3}$, the samples were stored at room temperature for 24 hours. On the second day, the dissolved samples were heated at $100{ }^{\circ} \mathrm{C}$ in a water bath for 20 minutes, then cooled and $1 \mathrm{ml}$ of $\mathrm{H}_{2} \mathrm{O}_{2}$ was added to each tube. After standing overnight, the samples were heated again at $100{ }^{\circ} \mathrm{C}$ for 1 hour and allowed to cool to room temperature. Finally, the solution was completed with $25 \mathrm{ml}$ of deionized water to ensure transparency for AAS analysis [18].

\subsection{Chromosome Analyses}

Chromosomal damage was evaluated by the examination of chromosomal preparations from bone marrow cells of each individual taken from polluted and non-polluted areas. For karyotyping, the Colchicine Hypotonic Citrate method was used [19]. The standard Giemsa-stained metaphase plates were photographed under the X100' immersion objective. Twenty metaphase plates were examined for each specimen and the structural anomalies were determined according to El-Refaiy et al. [20] and Aly et al. [21]. The chromosomal results are presented in Figures 2-3 and Table 3.

\section{RESULTS AND DISCUSSION}

\subsection{Heavy Metal Concentrations of the Samples}

According to the results of soil heavy metal analysis; Regulation on Control of Soil Pollution [22] and Regulation on the Use of Domestic and Urban Treatment Sludges in Soil [23]; The upper limits of the $\mathrm{Cd}$ are $3 \mathrm{ppm}$ and $1.5 \mathrm{ppm}$ respectively, which are exceeded in polluted area samples. The upper limit 
of the $\mathrm{Pb}$ is $100 \mathrm{ppm}$ and the concentration detected in the polluted area samples is above this value (Table 1). Other metal concentrations are below the acceptable ranges.

Table 1. Metal concentration in the analyzed soils $(\mathrm{mg} / \mathrm{kg}$ ) (mean, $\mathrm{n}=4$ for the polluted area and $\mathrm{n}=4$ for the non-polluted area, n: number of specimens)

\begin{tabular}{|l|c|c|c|c|c|c|}
\hline $\begin{array}{l}\text { Sampling Sites/Metal } \\
\text { concentrations }\end{array}$ & $\mathbf{Z n}$ & $\mathbf{C u}$ & $\mathbf{N i}$ & $\mathbf{C d}$ & $\mathbf{P b}$ & $\mathbf{P h}$ \\
\hline Polluted area/n=4 & 38.75 & 41.5 & 28.25 & 9 & 125.5 & 7.6 \\
\hline Non-polluted area/n=4 & 36.45 & 40.7 & 27.20 & 0.7 & 16.8 & 7.6 \\
\hline
\end{tabular}

Increasing industrialization has also brought environmental pollution which caused the deterioration of the ecological balance. The concentration of heavy metals in the soil above a certain level constitutes a danger for all living beings [24]. The comparison of acceptable metal concentrations between the European countries and Turkey revealed higher values of $\mathrm{Cd}, \mathrm{Cu}, \mathrm{Ni}$, and $\mathrm{Pb}$ in Turkey [25]. Research on heavy metal pollution caused by motor vehicles has indicated higher concentrations of $\mathrm{Cd}, \mathrm{Pb}, \mathrm{Ni}$, $\mathrm{Cu}$, and $\mathrm{Zn}$ in soils and plants [26,27]. From these metals, the high concentrations of $\mathrm{Cd}$ and $\mathrm{Pb}$ affect plants negatively and also disseminate to other organisms by the food chain [28]. The most important harmful effect of heavy metals on animals is the formation of reactive oxygen species (ROS). ROS, such as superoxide $\left(\mathrm{O}_{2}-\right)$, hydroxyl $\left(\mathrm{OH}^{-}\right)$, and hydrogen peroxide $\left(\mathrm{H}_{2} \mathrm{O}_{2}\right)$, are continuously produced at low levels during normal oxidative metabolism in biological systems. However, increased ROS formation due to exposure to chemical substances such as heavy metals generates oxidative stress, promoting harmful effects on DNA, lipids, and proteins and as a result, the functional impairments of enzymes and other important macromolecules happen [29].

According to investigations conducted on natural rodent species, the heavy metal contents in the liver, muscle, and kidneys of these animals were elevated due to the exposure to pesticides, fertilizers, and industrial wastes [30,31]. Schleich et al. [30] and Lourenço et al. [31] therefore, stated that some rodent species (Ctenomys talarum, Apodemus sylvaticus) are efficient and practical biological indicators in the determination of environmental pollution. In this study, the heavy metal concentrations in liver tissues of animals taken from sampling areas are given in Table 2. Accordingly, $\mathrm{Cd}$ and $\mathrm{Pb}$ concentrations in the samples taken from the polluted area were found to be higher than the samples taken from the non-polluted area. The findings from the tissue samples reflect the differences in the metal contents of both soils.

Table 2. Metal concentration in the liver tissues $(\mathrm{mg} / \mathrm{kg})(\mathrm{n}=3$ for the polluted area and $\mathrm{n}=2$ for the non-polluted area, $\mathrm{n}$ : number of specimens).

\begin{tabular}{lllllll}
\hline \hline Sampling Sites & $\mathbf{n}$ & $\mathbf{C d}$ & $\mathbf{C u}$ & $\mathbf{N i}$ & $\mathbf{P b}$ & $\mathbf{Z n}$ \\
\hline \hline Polluted area/n= 3 & 1 & 1.80 & 28.68 & 0.75 & 4.30 & 140.63 \\
& 2 & 2.05 & 27.51 & 0.87 & 5.80 & 170.80 \\
& 3 & 3.07 & 20.44 & 0.95 & 7.50 & 164.40 \\
\hline Total & 3 & 6.92 & 76.63 & 2.57 & 17.6 & 475.83 \\
\hline \hline Non-polluted area/n=2 & 1 & 0.21 & 19.60 & 0.70 & 0.54 & 75.20 \\
& 2 & 0.25 & 19.67 & 0.65 & 0.60 & 90.73 \\
\hline Total & 2 & 0.46 & 39.27 & 1.35 & 1.14 & 165.93 \\
\hline \hline
\end{tabular}

\subsection{Chromosomal Aberrations}

Animals of the genus Nannospalax show a high degree of chromosomal polymorphism $(2 n=36-60)$ due to the diversity observed in $2 \mathrm{n}$ (diploid chromosome number) and NF (fundamental number) values. In Bilecik province, there are two common cytotypes, $2 n=52 \quad N F=70$ and $2 n=60 \quad N F=78$ [32,33]. To eliminate the discrepancies caused by different cytotypes, only $2 n=60 \mathrm{NF}=78$ chromosomal forms distributed in the same region were examined in this study. The chromosome set of regionally distributed 
$N$. xanthodon species consists of 8 double bi-armed chromosomes and 22 double acrocentric chromosomes. The $\mathrm{X}$ chromosome is metacentric, while the $\mathrm{Y}$ chromosome is acrocentric as illustrated in Figure 2.

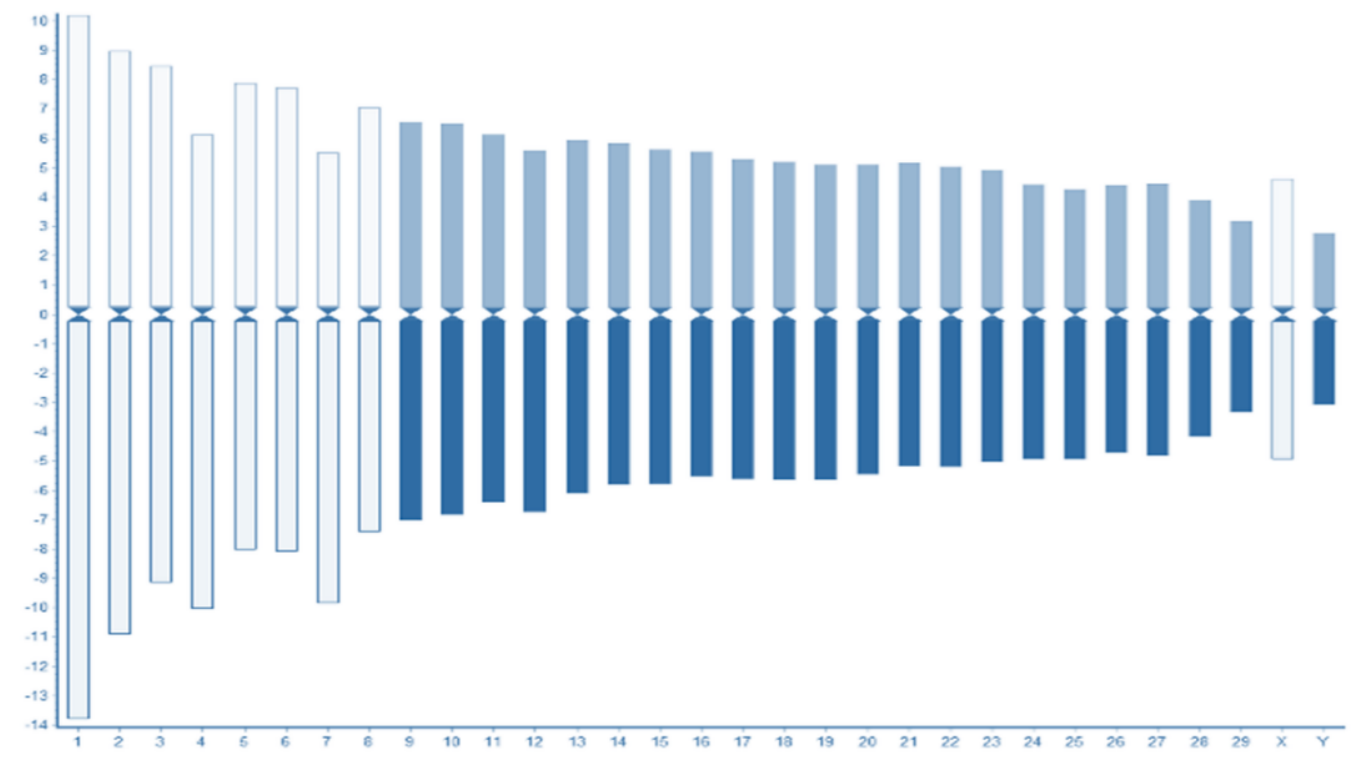

Figure 2. Ideogram of standard karyotype in N. xanthodon $(2 \mathrm{n}=60)$ (light-colored columns show the bi-armed chromosomes, dark-colored columns show the acrocentric chromosomes).

The examination of metaphase plates of the samples taken from the polluted area revealed a large number of chromosomal deletions, chromosomal rings, dicentric chromosomes, fragments, and the chromosomal end to ends compared to normal plates (Figure 3). To quantify the effect of metal pollution on chromosomes, 20 metaphase plates of each sample were examined and the chromosomal aberrations occurring in 100 cells in total are presented in Table 3. Accordingly, bone marrow cells of animals from the polluted group were found to have more fragments and deletions in chromosomes compared to the nonpolluted group.

Table 3. The number of chromosomal aberrations in the metaphase chromosome of $N$. xanthodon in polluted and nonpolluted areas (CD: chromosomal deletion, DC: dicentric chromosomes, CR: chromosomal ring and CF: fragments, EE: chromosomal end to end).

\begin{tabular}{lcllllll}
\hline \hline Sampling sites & $\begin{array}{l}\text { Number of } \\
\text { specimens }\end{array}$ & $\begin{array}{l}\text { Number of examined } \\
\text { metaphase plates }\end{array}$ & CD & DC & CR & CF & EE \\
\hline \hline Polluted area & 1 & 20 & 60 & 14 & 20 & 51 & 22 \\
& 2 & 20 & 42 & 17 & 16 & 35 & 17 \\
& 3 & 20 & 58 & 22 & 12 & 44 & 19 \\
& & & & & & & \\
\hline Total & 3 & 60 & 160 & 53 & 48 & 130 & 58 \\
\hline \hline Non-polluted area & 1 & 20 & 26 & 11 & 05 & 21 & 12 \\
& 2 & 20 & 31 & 08 & 07 & 25 & 17 \\
& & & & & & & \\
\hline Total & 2 & 40 & 57 & 19 & 12 & 46 & 29 \\
\hline \hline
\end{tabular}




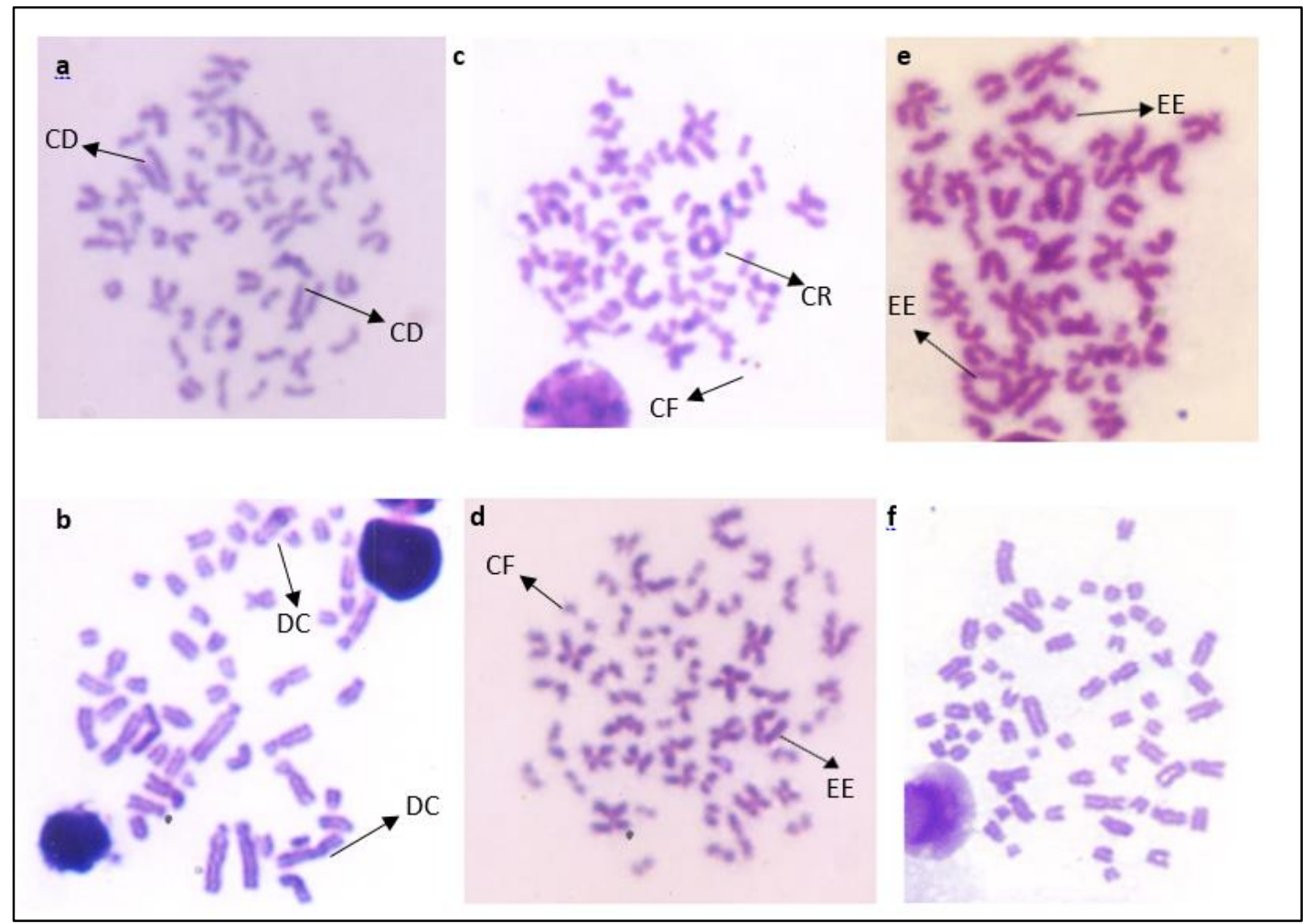

Figure 3. Metaphase plates of chromosomes in N. xanthodon, showing a) chromosomal deletion (CD), b) dicentric chromosomes (DC), c, d, and e) chromosomal ring (CR), chromosomal fragments (CF), and chromosomal end to end (EE), f) normal metaphase plate.

The toxic metal concentrations in the mammalian liver were previously reported as $\mathrm{Zn}>100, \mathrm{Ni}>2$, $\mathrm{Pb}>1, \mathrm{Cd}>1.5, \mathrm{Cu}>30$ [34]. However, the toxic metal concentrations in soil samples were estimated as $\mathrm{Zn}>90, \mathrm{Ni}>50, \mathrm{~Pb}>35 \mathrm{Cd}>0.35, \mathrm{Cu}>30$ [35]. Silva et al. [36] in their study on Ctenomys torquatus reported the $\mathrm{Pb}(2.9 \mathrm{mg} / \mathrm{kg}), \mathrm{Ni}(8.4 \mathrm{mg} / \mathrm{kg})$ and $\mathrm{Zn}(128.2 \mathrm{mg} / \mathrm{kg})$ values as toxic and also revealed genotoxic and cytogenetic damages (bone marrow, spleen, kidney, liver and lung cells) as a result of this toxicity. Metal levels determined in our study were also found toxic except for $\mathrm{Cu}$ and $\mathrm{Ni}$ and caused different modifications in bone marrow chromosomes. In studies on wild rodent and insectivorous species, the most common cause of chromosomal aberrations was attributed to $\mathrm{Pb}$ and $\mathrm{Cd}$ exposure [37-40]. However, it is also known that the various combinations of metals can induce or diminish chromosomal aberrations. Singh and Sankhla [41] reported that $\mathrm{CdCl}_{2}$ significantly increases the number of chromosomal aberrations in animals. $\mathrm{Zn}$ has been found to decrease the toxic effect by inhibiting $\mathrm{Cd}$ absorption in living organisms [42,43]. Compared to other terrestrial rodent and insectivore species which are known to be chromosomally affected by the accumulation of metals in the soil, N. xanthodonindividuals live a longer life under the soil. Since the accumulation of metal is affected by factors such as species, texture, sex, age, seasonal differences, and pollution level of the region, it seems very difficult to compare the toxic effect of metal accumulation in N. xanthodon with other species.

Blind mole rats develop multiple adaptive complexes when exposed to underground stress (darkness, energy expenditure to dig hard soil, low efficiency, nutrient shortage, hypoxia, hypercapnia), and in this way, they diversify both chromosomally and genetically [44]. As a common consensus, it is thought that the $2 \mathrm{n}$ variety seen in the genus Nannospalax originates from the Robertsonian translocations [45]. New chromosomal forms occur as a result of the fusion of the acrocentric chromosomes from the centromere regions or by dividing the chromosomes from the centromere region to generate two chromosomes. The pericentric inversions that cause the change of the 
centromere position affect the NF number due to the increase or decrease in the number of chromosomal arms $[46,47]$.

\section{CONCLUSIONS}

The determination of the impact of human activities on animal populations has a significant influence on wildlife conservation. The use of animals as a bioindicator of environmental pollution at the same time illustrates the biological risks for the human population. Therefore, the result of this study was reported to the facility and it was effective in the removal of that facility from the area. The increase in metal levels in liver tissue due to the environmental abundances of these metals in the soil indicates that these animals are candidate bioindicators for ecotoxicological investigations. A preliminary study on the determination of chromosomal aberrations in $N$. xanthodon will also contribute to their cytogenetic studies in addition to the Robertsonian translocations.

\section{REFERENCES}

[1] Dubovskiy IM, Grizanova EV, Ershova NS, Rantala MJ, Glupov VV. The effects of dietary nickel on the detoxification enzymes, innate immunity and resistance to the fungus Beauveria bassiana in the larvae of the greater wax moth Galleria mellonella. Chemosphere 2011; 85:9296.

[2] Sánchez-Chardi A, Ribeiro CAO, Nadal J. Metals in liver and kidneys and the effects of chronic exposure to pyrite mine pollution in the shrew Crocidura russula inhabiting the protected wetland of Doñana. Chemosphere 2009; 76:387-394.

[3] Marschner H. Mineral Nutrition of Higher Plants. London:Academic Press, 1995, pp. 299-312.

[4] Smith PN, Cobb GP, Godard-Codding C, Hoff D, McMurry ST, Rainwater TR, Reynolds KD. Contaminant exposure in terrestrial vertebrates. Environ Pollut 2007; 150:41-64.

[5] Talmage SS, Walton BT. Small mammals as monitors of environmental contaminants. Rev Environ Con Tox 1991; 119; 47-145.

[6] Sözen M. A biological investigation on Turkish Spalax Güldenstaedt, 1770 (Mammalia: Rodentia). GU J Sci 2005; 2:167-181.

[7] Yağcı T, Coşkun Y, Aşan N. Tunnel structure of blind mole rats (genus Nannospalax) in Turkey (Rodentia: Spalacidae).Zool. in the Mid. East 2010; 50: 35-40.

[8] Sharma N, Trikha P, Akhtar M, Raisuddin S. Inhibitory effect of Emblica officinalis on the in vivo clastogenicity of benzo[a]pyrene and cyclophosphamide in mice. Hum Exp Toxicol 2000; 22:643-653.

[9] Antonelli A, Portesi A, Cozzi E, Tradanico A, Bbalzarini R, Grigoloto P, Cosciani-Cunico PG. The collecting duct carcinoma of the kidney: a cytogenetical study. Eur Urol 2003; 43:680-685.

[10] Topashka-Ancheva M, Metcheva R, Teodorovab S. A comparative analysis of the heavy metal loading of small mammals in different regions of Bulgaria II: chromosomal aberrations and blood pathology. Ecotoxicol Environ Saf 2003; 54:188-193.

[11] Agarwal KA, Sharma A, Talukder G. Clastogenic effects of copper sulphate on the bone marrow chromosomes of mice in vivo. Mutation Research 1990; 243:1-6. 
[12] Nehez M, Lorencz R, Desi I. Simultaneous Action of Cypermethrin and Two Environmental Pollutant Metals, Cadmium and Lead, on Bone Marrow Cell Chromosomes of Rats in Subchronic Administration. Ecotoxicol Environ Saf 2000; 45:55-60.

[13] Mertens J, Luyssaert S, Verbeeren S, Vervaeke P, Lust N. Cd and Zn concentrations in small mammals and willow leaves on disposal facilities for dredged material. Environ Pollut 2001;115:17-22.

[14] Sanchez-Chardi A, Lopez-Fuster MJ, Nadal J. Bioaccumulation of lead, mercury, and cadmium in the greater white-toothed shrew, Crocidura russula, from the Ebro Delta (NE Spain): sexand age-dependent variation. Environ Pollut 2007a; 145:7-14.

[15] Sanchez-Chardi A, Marques CC, Nadal J, Mathias ML. Metal bioaccumulation in the greater white-toothed shrew, Crocidura russula, inhabiting an abandoned pyrite mine site. Chemosphere 2007b; 67:121-130.

[16] Yağc1 T, Aşan N. A live trap model for subterranean mole rats. Mammalia 2007; 71:98-99.

[17] Beernaert J, Scheirs J, Den Brande VG, Leirs H, Blust R, De Meulenaer B, Camp VJ, Verhagen $\mathrm{R}$. Do wood mice (Apodemus sylvaticus) use food selection as a means to reduce heavy metal intake?. Environ Pollut 2008; 151:599-607.

[18] Ajayi OA, Idowu, AB, Eromosele CO, Dedeke GA, Ademolu KO. Distribution and Effect of some Heavy Metals in Selected Organs and Tissues of Albino Rats Exposed to Vehicular Exhaust Fumes. Proceedings of the Environmental Management Conference, Federal University of Agriculture, Abeokuta, Nigeria, 2011, pp. 519-526

[19] Ford CE, Hamerton JL. A colchicine, hypotonic citrate, squash sequence for mammalian chromosomes. Stain Technol 1956; 31:247-251.

[20] El-Refaiy AI, Eissa FI. Histopathology and cytotoxicity as biomarkers in treated rats with cadmium and some therapeutic agents. Saudi J Biol Sci 2013; 20:265-280.

[21] Aly FM, Kotb AM, Seddik H. Effects of Spirulina platensis on DNA damage and chromosomal aberration against cadmium chloride-induced genotoxicity in rats. Environ Sci Pollut Res 2018; 11:829-836.

[22] Turkish Environmental Legislation: Regulations, Regulation on Control of Soil Pollution (Official Gazatte dated 31.05.2005 and no. 25831).

[23] Regulations on Using Domestic and Urban Treatment Sludges within Soil (Official Gazette dated 03.08.2010 and no. 27661)

[24] Benavides MP, Gallego SM, Tomaro LM. Cadmium tox icity in plants. Braz J Plant Physiol 2005; 17:21-34.

[25] ECDGE, European Commission Director General Environment. Heavy metals and organic compounds from wastes used as organic fertilizers. Final Report. July WPA Consulting Engineers İnc, 2010. 
[26] Viard B, Pihan F, Promeyrat S, Pihan J. Integrated Assessment of heavy metal ( $\mathrm{Pb}, \mathrm{Zn}, \mathrm{Cd})$ highway pollution:bioaccumulation in soil, Graminaceae and Land Snails. Chemosphere 2004; 55:1349-1359.

[27] Çelik A, Kartal AA, Akdoğan A, Kaska Y. Determining the heavy metal pollution in Denizli (Turkey) by using Robinia pseudo-acacia L. Environ. Int 2005; 31: 105-112.

[28] Vidhya L, Dhandapani M, Sekar M, Mahimairaja S. Lead pollution in soil, water and plants due to automobile emission in urban environments in Coimbatore. Madras Agric. $\mathbf{J}$ 2007;94: 89-96.

[29] Viegas-Crespo AM, Lopes PA, Pinheiro MT, Santos MC, Rodrigues PD, Nunes AC, Marques C, Mathias ML.Hepatic elemental contents and antioxidant enzyme activities in Algerian mice (Mus spretus) inhabiting a mine area in central Portugal.Sci. Total Environ 2003; 311: 101-109.

[30] Schleich CE, Beltrame MO, Carlos DA. Heavy metals accumulation in the subterranean rodent Ctenomys talarum (Rodentia: Ctenomyidae) from areas with different risk of contamination'. Folia Zool 2010; 2:108-114.

[31] Lourenço J, Pereira R, Gonçalves F, Mendo S. Metal bioaccumulation, genotoxicity and gene expression in the European wood mouse (Apodemus sylvaticus) inhabiting an abandoned uranium mining area. Sci. Total Environ 2013; 443:673-680.

[32] Arslan A, Kryštufek B, Matur F, Zima J. Review of chromosome races in blind mole rats (Spalax and Nannospalax). Folia Zool 2016; 4:249-301.

[33] Yağcı T. C- and NOR-banding karyotype analysis of Nannospalax xanthodon $(2 \mathrm{n}=52,2 \mathrm{n}=60$ ) and new locality for $2 \mathrm{n}=52$ cytotype from western Anatolia. Caryologia 2017; 71:7-12.

[34] SETAC-Society of Environmental Toxicology and Chemistry. Environmental contaminants in wildlife: interpreting tissue concentrations, in: W.N. Beyer, G.H. Heinz, A.W. RedmonNorwood (Eds.), CRC Lewis, Boca Raton, 1996, 494 pp.

[35] Freedman B. Toxic elements, in: B. Freedman (Ed.), Environmental Ecology: The Ecological Effects of Pollution, Disturbance, and Other Stresses, Academic Press, London, 1995, pp. 6293.

[36] Silva J, TRO Freitas, Heuser V, Marinho JR, Bittencourt F, Tadeu C, Cerski S, Kliemann LM, Erdtmann B. Effects of chronic exposure to coal in wild rodents (Ctenomys torquatus) evaluated by multiple methods and tissues. Mutation Research 2000; 470:39-51.

[37] Smith GJ, Rongstad OJ. Small mammal heavy metal concentrations from mined and control sites. Environ Pollut 1982; 28:121-134.

[38] Pankakoski E, Koivisto I, Hyvarinen H, Terhivuo J. Shrews as indicators of heavy metal pollution. Carnegie Museum Nat Hist Spec Publ. 1994; 18, 137-149.

[39] Komarnicki GJK. Tissue, sex and age specific accumulation of heavy metals $(\mathrm{Zn}, \mathrm{Cu}, \mathrm{Pb}, \mathrm{Cd})$ by populations of the mole (Talpa europaea L.) in a central urban area. Chemosphere 2000; 41:1593-1602. 
[40] Lopes PA, Viegas-Crespo AM, Nunes AC, Pinheiro T, Marques C, Santos MA, Mathias ML. Influence of age, sex, and sexual activity on trace element levels and antioxidant enzyme activities in field mice (Apodemus sylvaticus and Mus spretus). Biol Trace Elem Res 2002; 85:227-239.

[41] Singh P, Sankhla V. In situ protective effect of curcumin on cadmium chloride induced genotoxicity in bone marrow chromosomes of Swiss albino mice. J Cell Mol Biol 2010; 2: 5764.

[42] Jihen EH, Imed M, Fatima H, Abdelhamid K. Protective effects of selenium (Se) and zinc (Zn) on cadmium $(\mathrm{Cd})$ toxicity in the liver of the rat: effects on the oxidative stress. Ecotoxicol Environ Saf 2009; 5:1559-1564.

[43] Jemai H, Lachkar HA, Messaoudi I, Kerkeni A. Effect of zinc pre-treatment on blood glutathione, serum zinc and kidney histological organization in male rats exposed to cadmium. $\mathbf{J}$ Trace Elem Med B1o 2010; 4:277-288.

[44] Nevo E. Stress, adaptation, and speciation in the evolution of the blind mole rat, Spalax, in Israel. Mol. Phylogenetics Evol 2013; 66:515-525.

[45] Savic I, Nevo E.The Spalacidae; Evolutionary history, speciation and population biology, in; Evolution of Subterranean Mammals at the Organismal and Molecular Levels. Alan R. Liss New York: pp.129-153.

[46] Nevo E, Filippucci MG, Redi C, Korol A, Beiles A. Chromosomal speciation and adaptive radiation of mole rats in Asia Minor correlated with increased ecological stress. Proc Natl Acad Sci 1994b; 91: 8160-8164.

[47] Nevo E, Filippucci MG, Redi C, Simson S, Heth G, Beiles A. Karyotype and genetic evolution in speciation of subterranean mole rats of the genus Spalax in Turkey. Biol J Linn Soc 1995; 54: 203-229. 